\title{
Utilization aspects in a life cycle contract (the example of public transport in Russia)
}

\author{
N A Amosovi ${ }^{1}$ E Y Kuznetsova ${ }^{1,2}$, M A Prilutskaya ${ }^{1}$ and G R Kukushkina ${ }^{1}$ \\ ${ }^{1}$ Institute of New Materials and Technologies, Ural Federal University named after the \\ first President of Russia B.N. Yeltsin, 19, Mira street, Yekaterinburg, 620002, Russia \\ E-mail: ${ }^{2}$ e.y.kuznetsova@urfu.ru
}

\begin{abstract}
A structural analysis of public transport in Russia on the criterion 'passenger turnover' has been carried out in the last few years. Demand statistics have been compiled for all urban transport types. This has led to identify the quantitatively predominant types of public transport with a high pace of development. The article discusses the possibility of applying the life cycle contract concept to public transport in connection with the popularization of the concept on the one hand and the relevance of resolving organizational issues of exploitation public transport on the other. The article shows that public transport plays a key role in the total volume of citizens' movement in Russia, therefore a life cycle contract is applicable to it as a whole. And the final phase of the life cycle contract is about utilization. Federal State Statistics Service data on passenger transport should form the basis for the correct calculation of future production capacities of end-of-life vehicles processors. This is necessary for the effective realization of the stage of 'decline' of the life cycle contract.
\end{abstract}

\section{Introduction}

At present, Russia is developing a recycling system for all types of vehicles [1,2]. The differences between the various types of vehicles are significant, so that the specificities of each type should be taken into account at the initial stage of establishing a common utilization system. The investigation deals with urban public transport vehicles. [3,4]. Urban public transport is concerned with the people movement along a certain route at a specified frequency. This type of transport is considered in this article (with the exception of the city electric train).

In 2017, the total number of urban transport in Russia was 196.6 thousand units, which includes buses, underground railway carriages, trams, trolleybuses and inland water-borne transport. The study of public transport is very important because it is the basis for the structure of the citizens' movement in the city, and therefore it is a priority in the recycling creation. In addition, all countries have taken various measures to encourage citizens to use public transport instead of personal transport. This will help to improve the environment and reduce road congestion. In Russia, the introduction of a life cycle contract [5-7] on vehicles can bring public transport to a new level [8]. We pay special attention to the stage of disposal of vehicles that are going out of service for two reasons:

- currently, a large percentage of the operating rolling stock has increased wear;

- in the Russian Federation, there is no vehicle recycling system that takes into account all its technological and environmental features, and this is the most problematic element of the life cycle of rolling stock operation. 
15th International Conference on Industrial Manufacturing and Metallurgy

IOP Publishing

IOP Conf. Series: Materials Science and Engineering 966 (2020) 012098 doi:10.1088/1757-899X/966/1/012098

\section{Materials and methods. Overview of urban public transport in Russia}

The first stage of the analysis concerns the demand structure, namely, the urban transport types mostly used by the population were taken. Table 1 shows data on the passengers' transportation by public transport in the city traffic.

Table 1. Transportation of passengers by public transport in the city traffic (million people)*.

\begin{tabular}{|c|c|c|c|c|c|c|c|c|c|}
\hline $\begin{array}{l}\text { types of } \\
\text { urban } \\
\text { transport }\end{array}$ & 2005 & 2010 & 2015 & 2016 & 2017 & $\begin{array}{c}\text { Structural } \\
\text { share in } \\
2017\end{array}$ & $\begin{array}{c}\text { Base } \\
\text { index } \\
2017 / \\
2005\end{array}$ & $\begin{array}{c}\text { Base } \\
\text { index } \\
2017 / \\
2010\end{array}$ & $\begin{array}{c}\text { Chain } \\
\text { index } \\
2017 \\
/ 2016\end{array}$ \\
\hline bus & 9276 & 5920 & 5019 & 5158 & 5425 & 47.47 & 58.48 & 91.64 & 105.18 \\
\hline metro & 3574 & 3294 & 3337 & 3312 & 3298 & 28.86 & 92.28 & 100.12 & 99.58 \\
\hline trolleybus & 4653 & 2206 & 1616 & 1483 & 1376 & 12.04 & 29.57 & 62.38 & 92.78 \\
\hline $\begin{array}{l}\text { tram } \\
\text { inland }\end{array}$ & 4123 & 2079 & 1478 & 1397 & 1327 & 11.61 & 32.19 & 63.83 & 94.99 \\
\hline $\begin{array}{l}\text { water- } \\
\text { borne }\end{array}$ & 4.7 & 6.5 & 3.6 & 3.3 & 3 & 0.03 & 63.83 & 46.15 & 90.91 \\
\hline TOTAL & 21630.7 & 13505.5 & 11453.6 & 11353.3 & 11429 & 100 & 52.84 & 84.62 & 100.67 \\
\hline
\end{tabular}

* Calculated on the basis of data of the Federal State Statistics Service 'Transport of Russia 2018' [9].

The leader of urban transport is the bus. In 2017, 5.425 million people were transported in Russia. This represents almost half $(47.47 \%)$ of the total volume transportation of the public transport. The growth rate of bus passenger transport in 2016 and 2017 averaged $103.98 \%$, which characterizes the annual increase in demand.

The second place is taken by the metro and is the most stable in the number of passengers carried per year. In the last 3 years, the difference in the number of passengers is less than $1 \%$. However, the length of the metro and the number of underground railway carriages increased by an average of $2.38 \%$ and $2.65 \%$ respectively in 2015 and 2017.

Trolleybuses, trams and inland water-borne transport are the types of transport that have gradually reduced the number of carried passengers. The decrease is due to the reduction in the availability of rolling stock, which can be seen from the data presented in Table 2. The rolling stock is ageing naturally and no new rolling stock is being released.

Table 2. Availability number of rolling stock, thousand units*.

\begin{tabular}{lccc}
\hline \multicolumn{1}{c}{ Type of transport (thousand units) } & 2015 & 2016 & 2017 \\
\hline Tramcars & 8.0 & 7.8 & 7.7 \\
Trolleybuses & 10.2 & 10.0 & 9.4 \\
$\begin{array}{l}\text { Availability of river and lake vessels (passenger } \\
\text { and cargo-and-passenger vessels) }\end{array}$ & 1.9 & 2.0 & 1.3 \\
\hline
\end{tabular}

* Calculated on the basis of data of the Federal State Statistics Service 'Transport of Russia 2018' [9].

It should be noted that there is a general decrease in the use of public transport by passengers since 2005. It is associated with using personal cars.

The second stage - the 'passenger turnover' is used as an index for the urban transport analysis (Table 3).

The 'passenger turnover' shows not only a change in the demand for a particular type of urban transport, but also the efficiency of its use. An example of the most efficient transport is the metro. The metro passenger turnover coefficient is approximately at the same level for 12 years.

Based on the comparison of the tables 1 and 2, it can be concluded that the bus is the most demanded public transport in Russia, but not the most efficient.

The higher passenger turnover coefficient is due to three aspects (for example, the comparison of bus and metro): 
15th International Conference on Industrial Manufacturing and Metallurgy

IOP Publishing IOP Conf. Series: Materials Science and Engineering 966 (2020) 012098 doi:10.1088/1757-899X/966/1/012098

Table 3. Public transport passenger turnover by urban traffic (billion passenger-kilometers)*.

\begin{tabular}{lccccccccc}
\hline $\begin{array}{c}\text { Types of } \\
\text { urban } \\
\text { transport }\end{array}$ & 2005 & 2010 & 2015 & 2016 & 2017 & $\begin{array}{c}\text { Structural } \\
\text { share in } \\
2017\end{array}$ & $\begin{array}{c}\text { Base } \\
\text { index } \\
2017 / \\
2005\end{array}$ & $\begin{array}{c}\text { Base } \\
\text { index } \\
2017 /\end{array}$ & $\begin{array}{c}\text { Chain } \\
\text { index } \\
2010\end{array}$ \\
\hline metro & 43.4 & 42.4 & $4 ., 6$ & 44.1 & 44.1 & 47.47 & 101.61 & 104.01 & 100 \\
bus & 48.9 & 39.1 & 32.3 & 34.7 & 35.9 & 28.86 & 73.42 & 91.82 & 96.66 \\
trolleybus & 15 & 7.1 & 6 & 5.5 & 5.2 & 12.04 & 34.67 & 73.24 & 105.77 \\
tram & 13,5 & 6.7 & 4.8 & 4.6 & 4.3 & 11.61 & 31.85 & 64.18 & 106.98 \\
$\begin{array}{l}\text { inland water- } \\
\text { borne }\end{array}$ & 0.06 & 0.06 & 0.06 & 0.06 & 0.04 & 0.03 & 66.67 & 66.67 & 150 \\
\hline TOTAL & 120.96 & 95.7 & 88.06 & 89.36 & 90.04 & 100 & 74.44 & 94.09 & 99.24 \\
\hline
\end{tabular}

* Calculated on the basis of data of the Federal State Statistics Service 'Transport of Russia 2018' [9].

- Lots of passenger seats. For example, the underground railway carriages consist of many carriages, thus has far more passenger seats than any bus has.

- Correct design of route plans. The bus route can be created through 'empty zones', while the metro train lines are created according to the most demanded route. Under the 'empty zones' are supposed zones with stops that are in least demand. Therefore, the passenger turnover coefficient decreases with the increase of 'empty zones'.

- The distance between stops. Short distances between stops increase the number of potential passengers.

The above aspects lead to the conclusion that the correct value of the passenger turnover coefficient for each type of urban transport is individual, depending on the specifics of the route and the construction.

The third stage of the analysis involves the consideration of the structural share for each type of urban transport by working lifespan. Table 4 shows the structural analysis of urban transport in Russia by type and working lifespan.

Buses have the most favourable age structure. The buses working lifespan is divided into three age groups, which have a maximum difference of $13 \%$ in 2017. The fleet of buses is approaching the ideal proportion of 30/30/30, which will lead to the equivalent entry and exit of vehicles.

Age structure of all other urban transport types is negative. Trolleybuses, tramcars and underground railway carriage, river and lake vessels in their structure have about $40 \%$ of the fleet that has completed its working lifespan and should be decommissioned. This category is a candidate for utilization and recycling. The passengers' transportation on end-of-life vehicles can be hazardous and environmentally harmful. The general urban transport system is subject to increased volatility due to possible breakdowns of older rolling stock.

All types of public transport should have a structure in which the entry and exit of vehicles are carried out in an even manner. In Russia, most of the urban transport needs to be urgently updated.

\section{Results}

In general, over the last few years, urban public transport has been characterized by an increase in the use of 'flexible transport'. 'Flexible transport' is a transport which route can be changed without changing mobile systems. Bus is an example. Trams, trolleybuses and metro train are not included in this category, because when a route is changed, the entire system have to be changed. This situation naturally causes a lot of problems and a lot of costs. 'Flexible transport' has the largest areas coverage according to route construction, therefore the bus is the most demanded transport. Passengers try to choose the route in such a way as to get as close as possible to the required location. 
15th International Conference on Industrial Manufacturing and Metallurgy IOP Publishing IOP Conf. Series: Materials Science and Engineering 966 (2020) 012098 doi:10.1088/1757-899X/966/1/012098

Table 4. Structural analysis of buses by working lifespan*.

\begin{tabular}{|c|c|c|c|c|c|}
\hline \multicolumn{6}{|c|}{ Age structure of buses on the balance of organizations, $\%$} \\
\hline $\begin{array}{c}\text { Working lifespan, } \\
\text { years }\end{array}$ & 2005 year & 2010 year & 2015 year & 2016 year & 2017 year \\
\hline Up to 5 & 31 & 42 & 36 & 38 & 37 \\
\hline 5 to 10 & 24 & 29 & 41 & 38 & 38 \\
\hline More than 10 & 45 & 29 & 23 & 24 & 25 \\
\hline \multicolumn{6}{|c|}{ Age structure of tramcars, $\%$} \\
\hline $\begin{array}{c}\text { Working lifespan, } \\
\text { year }\end{array}$ & 2005 г. & 2010 г. & 2015 г. & 2016 г. & 2017 г. \\
\hline Up to 5 & 6 & 11 & 8 & 8 & 10 \\
\hline $5.1-10$ & 5 & 7 & 12 & 11 & 10 \\
\hline $10.1-15$ & 18 & 5 & 7 & 8 & 9 \\
\hline $15.1-20$ & 37 & 17 & 4 & 4 & 4 \\
\hline More than 20 & 34 & 60 & 69 & 69 & 67 \\
\hline \multicolumn{6}{|c|}{ Age structure of trolley buses, $\%$} \\
\hline Workinglifespan & 2005 г. & 2010 г. & 2015 г. & 2016 г. & 2017 г. \\
\hline Up to 5 & 21 & 24 & 19 & 17 & 16 \\
\hline 5.1 to 10 & 14 & 23 & 28 & 28 & 29 \\
\hline More than 10 & 65 & 53 & 53 & 55 & 55 \\
\hline \multicolumn{6}{|c|}{ Age structure of underground railway carriages, $\%$} \\
\hline Working lifespan & 2005 г. & 2010 г. & 2015 г. & 2016 г. & 2017 г. \\
\hline upto 5 & 7 & 12 & 22 & 23 & 22 \\
\hline 5. $1-10$ & 6 & 8 & 11 & 11 & 13 \\
\hline $10.1-15$ & 17 & 6 & 7 & 7 & 9 \\
\hline $15.1-20$ & 15 & 16 & 5 & 4 & 4 \\
\hline $20.1-25$ & 18 & 15 & 13 & 12 & 10 \\
\hline More than 25 & 37 & 43 & 42 & 43 & 42 \\
\hline \multicolumn{6}{|c|}{ Age structure of river and lake vessels, $\%$} \\
\hline Working lifespan & 2005 г. & 2010 г. & 2015 г. & 2016 г. & 2017 г. \\
\hline Up to 1969 & 38.0 & 32.7 & 28.6 & 28.6 & 25.5 \\
\hline $1970-1979$ & 23.5 & 20.0 & 17.4 & 17.4 & 16.9 \\
\hline 1980-1989 & 27.5 & 25.9 & 27.2 & 27.2 & 26.4 \\
\hline 1990-1999 & 7.0 & 7.6 & 7.7 & 7.7 & 7.6 \\
\hline $2000-2009$ & 4.0 & 13.8 & 12.4 & 12.4 & 13.8 \\
\hline $2010-2015$ & - & - & 6.7 & 6.7 & 9.8 \\
\hline
\end{tabular}

* Calculated on the basis of data of the Federal State Statistics Service 'Transport of Russia 2018' [9].

It can be concluded from the analysis that the priority transport for Russian citizens is metro and buses. In order to improve the urban transport system, it is first necessary to update the fleet of trams, trolleybuses and inland water-borne vessels.

All types of urban transport are very important and should work in a common structure, complementing each other. It is important to monitor changes in the population's demand for a particular route. The routes are designed by the local municipality depending on the economic efficiency and exploitation of the infrastructure of the particular type of transport. The municipality should undertake corrective measures to encourage all transport types for harmonious and interrelated work.

Public vehicles which are in a state of disrepair and have reached the end of their useful life must be utilized of. At present Russia does not have enough specialized facilities for their utilization. Lack of financial resources of the transport companies' owners, ineffective legislation concerning using the vehicles which have reached the end of their useful life are the reasons for the delay in the renewal of the fleet and the lack of demand for the utilization.

The total result is that the public transport system depends on the number, structure, condition of the fleet and the possibility of vehicles' utilization. Therefore, in order to systematize the quantity and 
structure, for timely maintenance and possibility of the vehicle utilization we propose to introduce a life cycle contract for the public transport exploitation.

\section{Discussion. The life cycle contract perspective for public transport}

The main problem of public transport in Russia is its structure. Trams, trolleybuses, water vessels, subway cars with on end-of-life working lifespan must be exploited to maintain a sufficient number of vehicles in the fleets to load all routes.

Restructuring should be carried out through the update of the fleet. When the authorities impose prohibitions on the exploitation of unusable (by age, or by technical condition) vehicles, the obligation to utilize the end-of-life vehicles will be introduced at the same time. The difficulty of the upgrade will be the inability to recycle and utilize the long-working lifespan urban vehicles.

It is possible to bring the industry to a new level of recycling and utilizing through the introduction of a life cycle contract. Life cycle contract means a contract for the manufacture, supply, maintenance and following utilization of a vehicle. In the implementation of a life cycle contract for a public transport vehicle, it is proposed to use foreign and domestic experience.

The first life cycle contract was concluded in the UK in 1992 based on the model 'Private Finance Initiative'. An example of a contract based on this model is a high-speed rail infrastructure project. This section connects London with the tunnel under the English Channel. The contract includes: financing, design, construction, exploitation, repair and maintenance of the railway line $[10,11]$.

In Spain, a life cycle contract was concluded in 2009 for the production of underground railway carriages with their subsequent maintenance in the amount of 302 units for Madrid. The purchase took place under a 17-year leasing scheme [10, 11].

In 2018, in Russia OOO 'Uralskiye lokomotivy' produced and delivered 90 'Sinara' main-line locomotives in accordance with the life cycle contract. The contract provides for 28 years of service. OOO 'STM- Servis' will be engaged in the maintenance of railway equipment. OOO 'STM-Servis' and OOO 'Uralskiye lokomotivy' are part of the Sinara Group [12].

An example of a life cycle contract in Russia is the contract of the Ministry of Defence with the enterprise 'KamAZ' for the supply and maintenance of military equipment. Unlike other examples, KamAZ should utilize the decommissioned military equipment [13].

\section{Conclusion}

Today, the implementation of all stages of the life cycle has been developed at a sufficient level, except for the final stage - 'decline'(utilization). Utilization means a complex technological chain of operations using special production facilities, which are not enough in Russia.

The introduction of a full cycle in life cycle contract will result in the following important utilization aspects:

1) the manufacturer will have to utilize and independently recycle the previously delivered vehicle in accordance with the life cycle contract, or enter into an agreement with a third-party organization specializing in the technological recycling operations implementation;

2) all costs associated with utilization and recycling are included in the cost of the vehicle;

3) the depreciable value of the vehicle is calculated by the manufacturer at the design stage (before the production process) and is deducted from the value of the vehicle to reduce the contract price. Utilization costs are accounted and the customer does not have to pay for depreciable value. The manufacturer will eventually sell the recycled scrap metal or use it locally, thereby obtaining the depreciable value of the vehicle. If the depreciable value is not deducted at the stage of the contract price calculation, then the manufacturer will receive a double depreciable value: from the employer when the contract conclusion and from the use of the recycled material as feedstock. Depreciable value should be calculated on the basis of whether the producer resold the recycled waste or uses it as a feedstock for its production;

4) the manufacturer maintains the vehicle throughout the entire period of operation, therefore, all parts that have failed, which have been replaced, are also utilized of by the manufacturer. 
Enterprises should move to a cyclical economy in their own industries to participate in life cycle contract transactions. Producers will be directly dependent on the quality of their product, as they will have to service their product not only during the warranty period, but during the working lifespan of the product. All replaced parts will need to be utilized, which will lead to additional costs that must be foreseen in advance.

The adoption of a life cycle contract can be the beginning of a vehicle utilization system development in Russia, which will make it possible to adjust the public transport system.

\section{References}

[1] Ignatov V I2016 Recycling fee: the path to the development of the industry in Russia or its further degradation? Polytematic network electronic scientific journal of the Kuban state agricultural university 121 pp 1190-206 DOI: 10.21515/1990-4665-121-075

[2] Kuznetsova E, Markina A, Parshina V and Amosov N 2020 Optimization of Locating of Recycling Facilities for Vehicles in the Region VIII International Scientific Siberian Transport Forum. TransSiberia 2019. Advances in Intelligent Systems and Computing(Electronic Materialsvol1115) ed. Z Popovic, A Manakovet al (Springer, Cham) pp 218-32 DOI: 10.1007/978-3-030-37916-2_23

[3] Privalova O A 2017 Research of the state and development of public transport as a logistics system in the infrastructure of megapolis Trends in the development of science and education 31-2 pp 36-7 DOI:10.18411/1j-31-10-2017-33

[4] Zueva O N, Zhuravskaya M A and Sidorenko A M 2018 Logistic Integration and Coordination of Urban Public Transport Management Journal of new economy 19-1 pp 51-61 DOI: 10.29141/2073-1019-2018-19-1-5

[5] Frolova E G 2015 Methods for the optimization of life cycle contracts in the construction of roads in the conditions of high inflation Actual directions of scientific researches of the xxi century: theory and practice 3 8-3 (19-3) pp 32-4 DOI:10.12737/15587

[6] Gerasimenko O A and Avilova Zh N 2017 Concept, signs and advantages of application of life cycle contracts as forms of state-private partnership in the region Bulletin of the Belgorod state technological university by V.G. Shukhova $\mathbf{4}$ pp 203-8 DOI: 10.12737/article 58e613383985b3.58961357

[7] Volodina P M and Frolov I E 2018 Russian Specification of the Life Cycle Contract Application for the State Defense Order Performance Scientific works: Institute of national economic forecasting of the RAS 16 p236-47 DOI: 10.29003/m263.sp_ief_ras2018/236-247

[8] Boreiko O, Teslyuk V, Zelinskyy A and Berezsky O 2017 Development of models and means of the server part of the system for passenger traffic registration of public transport in the 'smart' city Eastern european magazine of advanced technologies 1, 2 (85) pp 40-7 DOI: 10.15587/1729-4061.2017.92831

[9] Federal State Statistics Service 'Transport of Russia 2018' Available online: https://www.gks.ru/free_doc/doc_2018/transp18.pdf (accessed on 01.06.2020)

[10] Sazykina S A, Rastopchina Yu L, Boltenkov V I and Boltenkova Yu V 2016 Life cycle contracts as an example of public-private cooperation in Russia's transport business. Knowledge. Understanding. Skill 2 pp 168-78. DOI:10.17805/zpu.2016.2.15

[11] New mechanisms of public-private partnership in Russia (life cycle contracts). Official site of vegaslex.ru. Available online: https://www.vegaslex.ru/analytics/publications/54349/ (accessed on 01.06.2020)

[12] Ural locomotives fulfill annual contract for the production of 2ES6 electric locomotives. Official site of ulkm.ru. Available online: http://ulkm.ru/actions/uralskie-lokomotivyvypolnili-godovoj-kontrakt-po-proizvodstvu-elektrovozov-2es6/ (accessed on 01.06.2020)

[13] KamAZ will receive a military life cycle contract. Available online: https://lenta.ru/news/2013/07/12/kamaz/ (accessed on 01.06.2020) 